Article

\title{
Biogas Dry Reforming for Hydrogen through Membrane Reactor Utilizing Negative Pressure
}

\author{
Akira Nishimura ${ }^{1, *(\mathbb{D}}$, Tomohiro Takada ${ }^{1}$, Satoshi Ohata ${ }^{1}$ and Mohan Lal Kolhe ${ }^{2}$ \\ 1 Division of Mechanical Engineering, Graduate Shool of Engineering, Mie University, Tsu, \\ Mie 514-8507, Japan; nisiaki531@ybb.ne.jp (T.T.); 420m111@m.mie-u.ac.jp (S.O.) \\ 2 Faculty of Engineering \& Science, University of Agder, 4879 Grimstad, Norway; mohan.1.kolhe@uia.no \\ * Correspondence: nisimura@mach.mie-u.ac.jp; Tel.: +81-59-231-9747
}

check for updates

Citation: Nishimura, A.; Takada, T.; Ohata, S.; Kolhe, M.L. Biogas Dry Reforming for Hydrogen through Membrane Reactor Utilizing Negative Pressure. Fuels 2021, 2, 194-209. https://doi.org/10.3390/ fuels2020012

Academic Editor: Timothy Lipman

Received: 1 April 2021

Accepted: 17 May 2021

Published: 19 May 2021

Publisher's Note: MDPI stays neutral with regard to jurisdictional claims in published maps and institutional affiliations.

Copyright: (C) 2021 by the authors. Licensee MDPI, Basel, Switzerland. This article is an open access article distributed under the terms and conditions of the Creative Commons Attribution (CC BY) license (https:/ / creativecommons.org/licenses/by/ $4.0 /)$.

\begin{abstract}
Biogas, consisting of $\mathrm{CH}_{4}$ and $\mathrm{CO}_{2}$, is a promising energy source and can be converted into $\mathrm{H}_{2}$ by a dry reforming reaction. In this study, a membrane reactor is adopted to promote the performance of biogas dry reforming. The aim of this study is to investigate the effect of pressure of sweep gas on a biogas dry reforming to get $\mathrm{H}_{2}$. The effect of molar ratio of supplied $\mathrm{CH}_{4}: \mathrm{CO}_{2}$ and reaction temperature is also investigated. It is observed that the impact of $p_{\text {sweep }}$ on concentrations of $\mathrm{CH}_{4}$ and $\mathrm{CO}_{2}$ is small irrespective of reaction temperature. The concentrations of $\mathrm{H}_{2}$ and $\mathrm{CO}$ increase with an increase in reaction temperature $t$. The concentration of $\mathrm{H}_{2}$, at the outlet of the reaction chamber, reduces with a decrease in $p_{\text {sweep. }}$. It is due to an increase in $\mathrm{H}_{2}$ extraction from the reaction chamber to the sweep chamber. The highest concentration of $\mathrm{H}_{2}$ is obtained in the case of the molar ratio of $\mathrm{CH}_{4}: \mathrm{CO}_{2}=1: 1$. The concentration of $\mathrm{CO}$ is the highest in the case of the molar ratio of $\mathrm{CH}_{4}: \mathrm{CO}_{2}=1.5: 1$. The highest sweep effect is obtained at reaction temperature of $500{ }^{\circ} \mathrm{C}$ and $p_{\text {sweep }}$ of $0.045 \mathrm{MPa}$.
\end{abstract}

Keywords: biogas dry reforming; membrane reactor; Ni catalyst; pressure difference provided by vacuum pump; initial temperature for dry reforming; molar ratio of $\mathrm{CH}_{4}: \mathrm{CO}_{2}$

\section{Introduction}

Global warming problem is a serious issue in the world. Each country has set the goal to reduce $\mathrm{CO}_{2}$ emission, by 2030 or 2050. For instance, the Japan had declared to reduce the amount of $\mathrm{CO}_{2}$ emission up to zero practically by 2050 . Though there are many ways to reduce the amount of $\mathrm{CO}_{2}$ emission, such as a digested sewage sludge for $\mathrm{CO}_{2}$ removal from biogas [1] and a production of high-quality hydrocarbon fuel from palm waste [2], a renewable $\mathrm{H}_{2}$ is a promising candidate. Renewable $\mathrm{H}_{2}$, which is called a green $\mathrm{H}_{2}$, can assist to solve the global warming and construct an energy supply chain to meet the increasing energy demand. There are some innovative approaches for green $\mathrm{H}_{2}$ production. $\mathrm{H}_{2}$ production by the water splitting over $\mathrm{Fe}_{3} \mathrm{O}_{4}$ pellet at low temperature of $250{ }^{\circ} \mathrm{C}, 290{ }^{\circ} \mathrm{C}$ and $310^{\circ} \mathrm{C}$ [3] and photothermal-photocatalytic materials under light illumination without additional energy [4] were reported. In addition, the anion exchange membrane (AEM) electrolysis for large-scale $\mathrm{H}_{2}$ production was investigated to clarify the resistances involved in AEM electrolysis [5].

This study focuses on $\mathrm{H}_{2}$ produced from a biogas dry reforming. Biogas is a gaseous fuel consisting of $\mathrm{CH}_{4}(55-75 \mathrm{vol} \%)$ and $\mathrm{CO}_{2}$ (25-45 vol\%) [6], mainly produced from fermentation by the action of anaerobic microorganisms on raw materials such as, garbage, livestock excretion, and sewage sludge. Additionally, the conversion of biogas to $\mathrm{H}_{2}$ can be said as a carbon neutral since the $\mathrm{CO}_{2}$, which is a by-product in the biogas production process, can be absorbed by plants. It is known from the International Energy Agency (IEA) [7] that the biogas has been produced 59.3 billion $\mathrm{m}^{3}$ globally with an equivalent energy of 1.36 EJ in 2018, which is approximately five times as large as that in 2000. Therefore, a biogas is thought to be a promising energy source. 
It is generally known that a biogas is used as a fuel for gas engine or micro gas turbine [8]. Biogas contains $\mathrm{CO}_{2}$ of approximately $40 \mathrm{vol} \%$ which reduces the heating value compared to a natural gas, resulting in the efficiency of power generation decreasing. Considering it, this study focuses on a biogas dry reforming to produce $\mathrm{H}_{2}$, which can be used as a fuel in the fuel cell system, such as solid oxide fuel cell (SOFC). Biogas dry reforming has been studied previously by several researchers [9-27]. The catalyst development, which is one of important issues, is investigated to improve the performance of biogas dry reforming. Several catalysts such as Co-Ni/ $\mathrm{Al}_{2} \mathrm{O}_{3}, \mathrm{Ce}-\mathrm{Co}-$

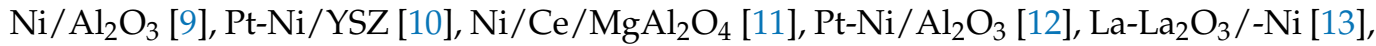
$\mathrm{Pd}-\mathrm{Ni}-\mathrm{Mg} /$ Ceria-Zirconia [14], $\mathrm{Ni} / \gamma-\mathrm{Al}_{2} \mathrm{O}_{3}$ [15], Ni/SBA-15 [16], Ni/ZnO- $-\mathrm{Al}_{2} \mathrm{O}_{3}$ [17], $\mathrm{Ni} / \mathrm{CeO}_{2}-\mathrm{SiO}_{2}$ [18], $\mathrm{Ni} / \mathrm{ZrO}_{2}$ [19], Ni/CaZrNiOx [20], Ni/CaFe $\mathrm{O}_{4}$ [21], $\mathrm{Ni} / \mathrm{Ce} / \mathrm{TiO}_{2}-$ $\mathrm{Al}_{2} \mathrm{O}_{3}$ [22], Ni nanoparticle [23], Ni/ZnO-CeO 2 [24], $\mathrm{Rh} / \mathrm{Ni}$ [25], Ni-based bimodal porous catalyst [26] and $\mathrm{Cu} / \mathrm{Ni}$ bimetallic catalyst [27] have been investigated, resulting that $\mathrm{Ni}$ based catalyst is the most common catalyst for the biogas dry reforming process. Therefore, $\mathrm{Ni}$ catalyst is adopted in this study. In addition, a membrane reactor is also adopted to improve the efficiency of biogas dry reforming in this study. It is well-known that a membrane reactor is used to improve the $\mathrm{CH}_{4}$ steam reforming by separating $\mathrm{H}_{2}$ from the reaction space [28-30] as soon as it is produced. The synergetic effect of the membrane reactor on performing the reaction and the separation in the same unit should be analyzed. It requires advanced levels of automation and control to re-design process [31]. Pd based membrane is used to separate $\mathrm{H}_{2}$ due to its high efficiency [31-33]. According to the literature survey, $\mathrm{Pd}$ membrane has been used to improve the performance of $\mathrm{CH}_{4}$ dry reforming [34-44]. The coupled effect of membrane and catalyst on $\mathrm{CH}_{4}$ conversion has been discussed earlier [31]. Alloy membrane such as $\mathrm{Pd} / \mathrm{Ag}[34-36], \mathrm{Pd} / \mathrm{Au}[37,38]$ and $\mathrm{Pd} / \mathrm{Cu}[39,40]$ have been used generally due to the stability at high temperature [32]. Hollow fiber membrane reactor can perform $\mathrm{CH}_{4}$ conversion, which has higher by $72 \%$ output than traditional fixed bed reactor [41]. The $\mathrm{Pd} / \mathrm{Au}$ alloy membrane has been used in the two-zone fluidized bed reactor $[33,42]$ and showed $\mathrm{CH}_{4}$ conversion and $\mathrm{H}_{2}$ selectivity to be higher compared to the conventional fluidized bed reactor. Reaction combination consisting of dry reforming and steam reforming has been carried out in a $\mathrm{Pd} / \mathrm{Ag}$ membrane reactor, resulting that $\mathrm{CH}_{4}$ conversion above $90 \%$ has achieved at $650{ }^{\circ} \mathrm{C}$ [36]. The effect of flow rate of sweep gas on $\mathrm{CH}_{4}$ conversion has been investigated by two membrane reactors, equipped with the expensive dense $\mathrm{H}_{2}$ selective membrane and the inexpensive porous Vycor glass membrane [43]. There has been a significant loss of the reactant with an increase in sweep gas flow rate, which in turn can decrease the $\mathrm{CH}_{4}$ conversion. The other study [35], which has investigated the effect of flow rate of sweep gas and reported that $\mathrm{CH}_{4}$ conversion and $\mathrm{H}_{2}$ recovery have increased with an increase in the flow rate of sweep gas. In addition, it is also reported that the increase in reaction pressure has showed the negative effect on $\mathrm{CH}_{4}$ conversion at the reaction temperature of $550{ }^{\circ} \mathrm{C}$ [35]. However, the other study [44] has reported a contrary conclusion that in $\mathrm{CH}_{4}$ conversion, $\mathrm{H}_{2}$ recovery and $\mathrm{H}_{2} / \mathrm{CO}$ ratio have increased with an increase in reaction pressure at the reaction temperature of $800{ }^{\circ} \mathrm{C}$. It [44] has also reported that $\mathrm{H}_{2} / \mathrm{CO}$ ratio has decreased with the increase in $\mathrm{CO}_{2} / \mathrm{CH}_{4}$ ratio. Since the $\mathrm{H}_{2}$ flux through membrane has increased with transmembrane pressure difference [34], it is expected that the performance of biogas dry reforming has been improved due to the shift of the reaction toward further conversion [31]. Though the impact of negative pressure of sweep gas on $\mathrm{H}_{2}$ diffusion flux has been reported [45], and at this moment, there is no study investigating the effect of negative pressure of sweep gas on the performance of biogas dry reforming.

Therefore, the aim of this study is to understand the effect of pressure of sweep gas ( $\left.p_{\text {sweep }}\right)$ on the performance of the biogas dry reforming process. In this study, the pressure difference was provided by vacuum pomp as the negative pressure. The effect of changing reaction temperature, which means the initial temperature for dry reforming in this study, from $400{ }^{\circ} \mathrm{C}$ to $600{ }^{\circ} \mathrm{C}$, and the molar ratio of $\mathrm{CH}_{4}: \mathrm{CO}_{2}$ by 1.5:1, 1:1 and 1:1.5 is also investigated. The molar ratio of $\mathrm{CH}_{4}: \mathrm{CO}_{2}=1.5: 1$ simulates a biogas. Since a pure 
Pd membrane has relatively high solubility for carbon, it causes membrane degradation leading to the loss of permeability [46]. Therefore, the $\mathrm{Pd} / \mathrm{Cu}$ alloy membrane is used in this study. The reaction scheme of $\mathrm{CH}_{4}$ dry reforming is as follows:

$$
\mathrm{CH}_{4}+\mathrm{CO}_{2} \leftrightarrow 2 \mathrm{CO}+2 \mathrm{H}_{2}
$$

The other reaction schemes which can be thought to be occurred in this study are as follows [32]:

$$
\begin{gathered}
\mathrm{CO}_{2}+\mathrm{H}_{2} \leftrightarrow \mathrm{CO}+\mathrm{H}_{2} \mathrm{O} \\
\mathrm{CH}_{4}+\mathrm{H}_{2} \mathrm{O} \leftrightarrow \mathrm{CO}+3 \mathrm{H}_{2} \\
\mathrm{CO}_{2}+4 \mathrm{H}_{2} \leftrightarrow \mathrm{CH}_{4}+2 \mathrm{H}_{2} \mathrm{O}
\end{gathered}
$$

where Equation (2) is the reverse water gas shift reaction (RWGS), Equation (3) is steam reforming of $\mathrm{CH}_{4}$ and Equation (4) is the methanation reaction.

\section{Experimentation}

\subsection{Experimental Set-Up}

Figure 1 illustrates the schematic drawing of experimental set-up used in this study. The experimental apparatus is composed of a gas cylinder, mass flow controllers (S48-32; produced by HORIBA METRON INC., Shanghai, China), pressure sensors (KM31; produced by NAGANO KEIKI, Tokyo, Japan), valves, a vacuum pump, a Pirani gauge (SW-1; produced by ULVAC, Saito-City, Miyazaki, Japan) for measuring negative pressure, a reactor consisting of reaction chamber and sweep chamber, and gas sampling taps. The reactor is in the furnace. The temperature in the furnace is controlled by far-infrared heaters (MCHNNS1; produced by MISUMI, Tokyo, Japan). $\mathrm{CH}_{4}$ gas whose purity is over $99.4 \mathrm{vol} \%$ and $\mathrm{CO}_{2}$ gas whose purity is over $99.9 \mathrm{vol} \%$ are controlled by the mass flow controllers and mixed before the reactors. The pressure of the mixed gas is measured by pressure sensors. Ar gas whose purity is over $99.99 \mathrm{vol} \%$ is controlled by the mass flow controller, and the pressure of Ar gas is measured by the pressure sensor, which is supplied as a sweep gas. The exhausted gas at the outlet of the reactor is suctioned by a gas syringe via the gas sampling tap. The concentration of sampled gas is measured by FID gas chromatography and a methanizer whose minimum resolution of both FID gas chromatograph and methanizer is $1 \mathrm{ppmV}$. The gas pressure at the outlet of the reactor is measured by the pressure sensor. The gas concentration and pressure are measured at the outlet of the reaction chamber and sweep chamber, respectively. A valve is installed next to the pressure gauge at the outlet of the reaction chamber to investigate the effect of $p_{\text {sweep }}$ on the performance of $\mathrm{CH}_{4}$ dry reforming. When the valve is closed, the gas in the reaction chamber flows to the sweep chamber preferentially.

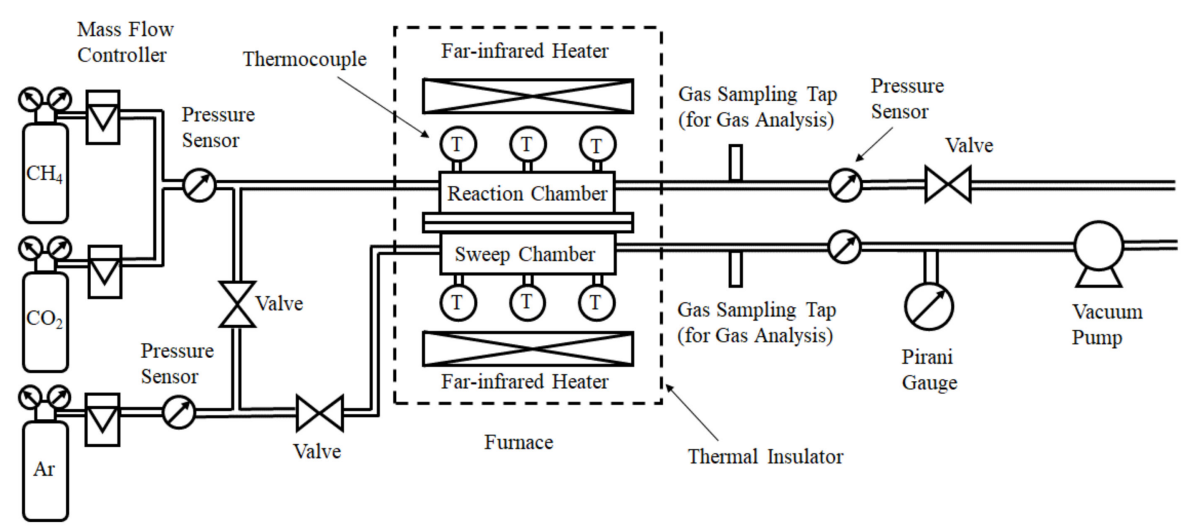

Figure 1. Schematic of experimental set-up. 
Figure 2 shows the detail and photo of the reactor. The reactor is composed of a reaction chamber, a sweep chamber, and $\mathrm{anH}_{2}$ separation membrane. The reaction chamber and the sweep chamber are made of stainless steel, which has a size of $40 \mathrm{~mm} \times 100 \mathrm{~mm} \times 40 \mathrm{~mm}$. The reaction space has a volume of $16 \times 10^{-5} \mathrm{~m}^{3}$. Porous pure Ni catalyst is placed in the reaction chamber. The average pore diameter of the catalyst is $1.9 \mathrm{~mm}$. The weight of the catalyst is $63.1 \mathrm{~g}$. The $\mathrm{Pd} / \mathrm{Cu}$ alloy membrane $(\mathrm{Cu}$ of $40 \mathrm{wt} \%$; produced by Tanaka Kikinzoku Kogyo, Tokyo, Japan) installed between reaction and separation chambers can provide $\mathrm{H}_{2}$ separation. The thickness of the $\mathrm{Pd} / \mathrm{Cu}$ alloy membrane is $60 \mu \mathrm{m}$. The temperatures at the inlet, middle, and outlet of the reaction and sweep chambers are measured using K-type thermocouples. The measured temperature and pressure are collected by the data logger (GL240; produced by Graphtec Corporation, Kanagawa, Japan).
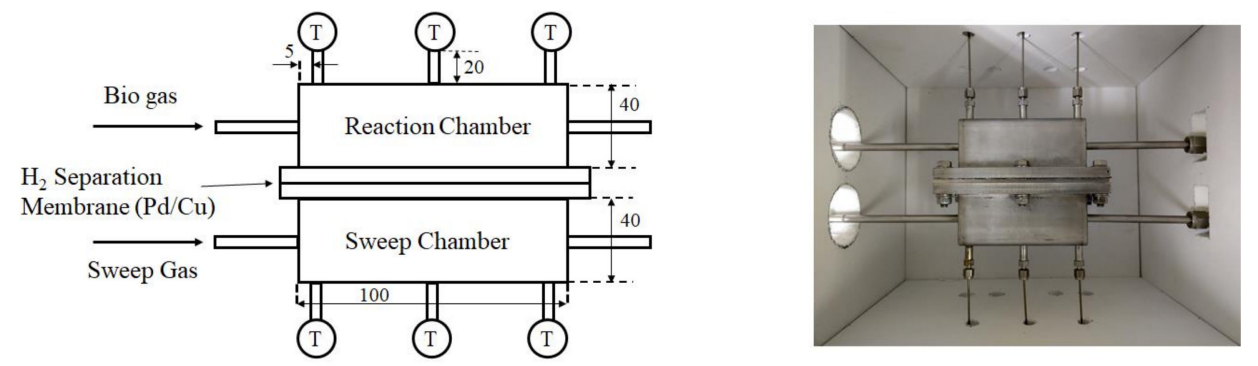

Figure 2. Schematic detail and photo of reactor.

Table 1 lists the experimental parameters in this study. The molar ratio of the supplied $\mathrm{CH}_{4}: \mathrm{CO}_{2}$ is changed at 1.5:1, 1:1 or 1:1.5, where $\mathrm{CH}_{4}: \mathrm{CO}_{2}=1.5: 1$ simulates a biogas. The feed ratio of sweep gas, defined as the flow rate of sweep gas divided by the flow rate of supply gas composed of $\mathrm{CH}_{4}$ and $\mathrm{CO}_{2}$ is set at 1.0 since the best performance of $\mathrm{CH}_{4}$ dry reforming was obtained at the feed ratio of sweep gas at 1 according to the authors' previous study [47]. The pressure in the sweep chamber is changed by $0.10 \mathrm{MPa}, 0.09 \mathrm{MPa}$ and $0.045 \mathrm{MPa}$ by means of vacuum pump and Pirani gauge. The effect of molar ratio on the performance of $\mathrm{CH}_{4}$ dry reforming has been investigated changing the reaction temperature of $400{ }^{\circ} \mathrm{C}, 500{ }^{\circ} \mathrm{C}$ and $600{ }^{\circ} \mathrm{C}$. The gas concentrations in reaction and sweep chambers have been evaluated by FID gas chromatograph (produced by GL Science, Nishi Shinjuku, Japan) and methanizer (produced by GL Science). This study shows the average data of five trials for each experimental condition in the following figures. The distribution of each gas concentration has been below $10 \% . \mathrm{H}_{2}$ selectivity and $\mathrm{CO}$ selectivity have also been evaluated.

Table 1. Experimental parameters.

\begin{tabular}{ll} 
Reaction temperature $\left({ }^{\circ} \mathrm{C}\right)$ & $400,500,600$ \\
Pressure of supply gas $(\mathrm{MPa})$ & 0.10 \\
Pressure of sweep gas, $p_{\text {sweep }}(\mathrm{MPa})$ & $0.10,0.09,0.045$ \\
Temperature of supply gas $\left({ }^{\circ} \mathrm{C}\right)$ & 25 \\
Molar ratio of supplied $\mathrm{CH}_{4}: \mathrm{CO}_{2}$ & $1.5: 1,1: 1,1: 1.5$ \\
(Flow rate of $\mathrm{CH}_{4}$ and $\left.\mathrm{CO}_{2}(\mathrm{NL} / \mathrm{min})\right)$ & $(1.088: 0.725,0.725: 0.725,0.725: 1.088)$ \\
Feed ratio of sweep gas & 1.0 \\
\hline
\end{tabular}

\subsection{Performance Evaluation of Proposed Reactor}

The performance of the proposed reactor is evaluated by gas concentration at the outlet of reaction and sweep chambers, $\mathrm{H}_{2}$ selectivity and $\mathrm{CO}$ selectivity. $\mathrm{H}_{2}$ selectivity $\left(S_{\mathrm{H} 2}\right)$ and $\mathrm{CO}$ selectivity $\left(S_{\mathrm{co}}\right)$ are defined as following:

$$
\begin{aligned}
& S_{\mathrm{H} 2}=C_{\mathrm{H} 2 \text {, out }} /\left(C_{\mathrm{H} 2 \text {, out }}+C_{\mathrm{CO}, \text { out }}\right) \times 100 \\
& S_{\mathrm{CO}}=C_{\mathrm{CO} \text {, out }} /\left(C_{\mathrm{H} 2 \text {, out }}+C_{\mathrm{CO} \text {, out }}\right) \times 100
\end{aligned}
$$


where $S_{\mathrm{H} 2}$ is $\mathrm{H}_{2}$ selectivity (\%), $\mathrm{C}_{\mathrm{H} 2 \text {, out }}$ is the concentration of $\mathrm{H}_{2}$ at the outlet of reaction and sweep chambers (ppmV), $C_{\mathrm{CO}}$, out is the concentration of $\mathrm{CO}$ at the outlet of reaction chamber (ppmV), and $S_{\mathrm{CO}}$ is the CO selectivity (\%).

In addition, this study also evaluates the performance of the proposed reactor by $\mathrm{CH}_{4}$ conversion $\left(X_{\mathrm{CH} 4}\right), \mathrm{CO}_{2}$ conversion $\left(X_{\mathrm{CO} 2}\right)$ and $\mathrm{H}_{2}$ yield $\left(Y_{\mathrm{H} 2}\right)$. This study defines $X_{\mathrm{CH} 4}$ and $X_{\mathrm{CO} 2}$ following Equation (1). $X_{\mathrm{CH} 4}, X_{\mathrm{CO} 2}$ and $Y_{\mathrm{H} 2}$ are defined as follows:

$$
\begin{aligned}
& X_{\mathrm{CH} 4}=\left(2 C_{\mathrm{H} 2, \text { out }}\right) /\left(C_{\mathrm{CH} 4, \text { in }}\right) \times 100 \\
& X_{\mathrm{CO} 2}=\left(2 C_{\mathrm{CO}, \text { out }}\right) /\left(C_{\mathrm{CO} 2, \text { in }}\right) \times 100 \\
& Y_{\mathrm{H} 2}=\left(1 / 2 C_{\mathrm{H} 2, \text { out }}\right) /\left(C_{\mathrm{CH} 4, \text { in }}\right) \times 100
\end{aligned}
$$

\section{Results and Discussion}

3.1. Effect of Pressure of Sweep Gas on the Performance of Dry Reforming under Different Reaction Temperatures

Figures 3-5 compare relationship between the concentrations of $\mathrm{CH}_{4}, \mathrm{CO}_{2}, \mathrm{H}_{2}$ and $\mathrm{CO}$ at the outlet of the reaction chamber changing reaction temperature, respectively. Reaction temperature is varied to $400{ }^{\circ} \mathrm{C}, 500{ }^{\circ} \mathrm{C}$, or $600{ }^{\circ} \mathrm{C}$. In these figures, the molar ratio of the supplied $\mathrm{CH}_{4}: \mathrm{CO}_{2}$ is 1.5:1. In addition, the error bars are also shown in these figures.

It is seen from Figure 3 that the impact of $p_{\text {sweep }}$ on concentrations of $\mathrm{CH}_{4}$ and $\mathrm{CO}_{2}$ is a little, while the concentration of $\mathrm{CH}_{4}$ at the reaction temperature of $600^{\circ} \mathrm{C}$ decreases with a decrease in $p_{\text {sweep }}$. It is believed that $\mathrm{H}_{2}$ separation is promoted with a decrease in $p_{\text {sweep }}$, resulting that $\mathrm{CH}_{4}$ is consumed more. However, it is found from Figure 3 that the change in concentration of $\mathrm{CO}_{2}$ with increase in reaction temperature is a small. Since the kinetic rates expressed by Arrehenius type of Equations (1), (2) and (4), which consume $\mathrm{CO}_{2}$ in the reaction, are much smaller than that of Equation (3) [11], it is believed that the impact of the reaction temperature on the concentration of $\mathrm{CO}_{2}$ is a small. Though this study focuses on $\mathrm{CH}_{4}$ dry reforming, $\mathrm{H}_{2} \mathrm{O}$, which is the by-product in the reaction as shown in Equation (3), might be produced, resulting that the consumption of $\mathrm{CH}_{4}$ is larger than that of $\mathrm{CO}_{2}$ at the reaction temperature of $600{ }^{\circ} \mathrm{C}$ due to the higher reaction rate of Equation (3) [11].

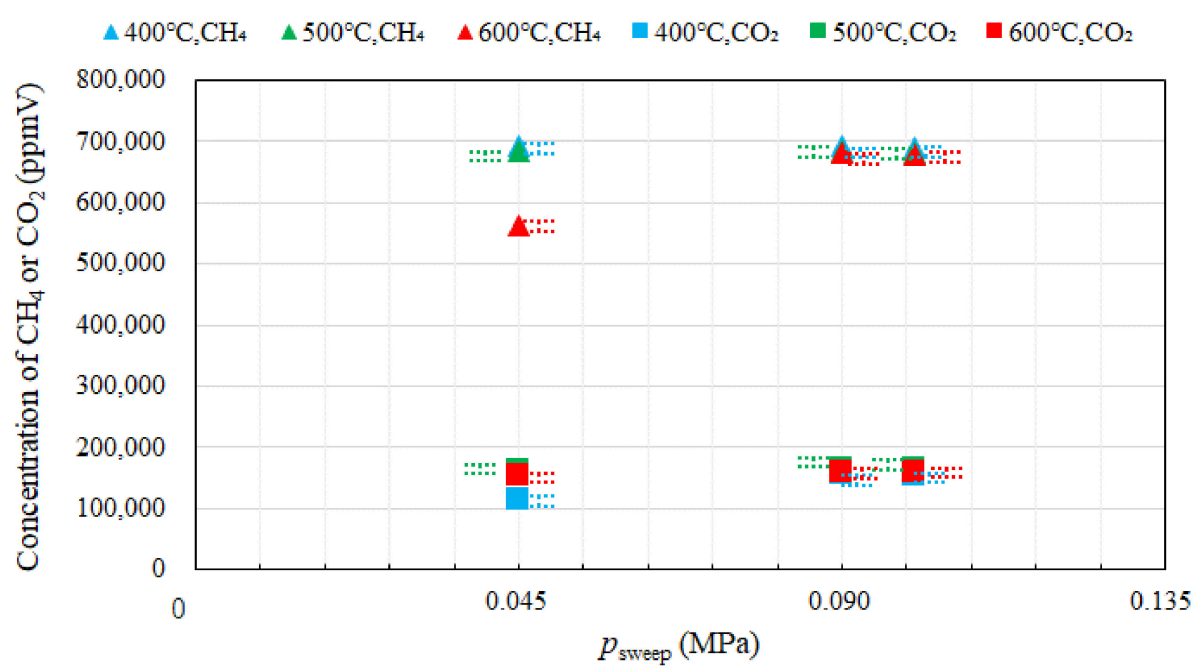

Figure 3. Impact of concentrations of $\mathrm{CH}_{4}$ and $\mathrm{CO}_{2}$ at the outlet of reaction chamber and $p_{\text {sweep }}$ with change in reaction temperature. $\left(\mathrm{CH}_{4}: \mathrm{CO}_{2}=1.5: 1\right)$. 


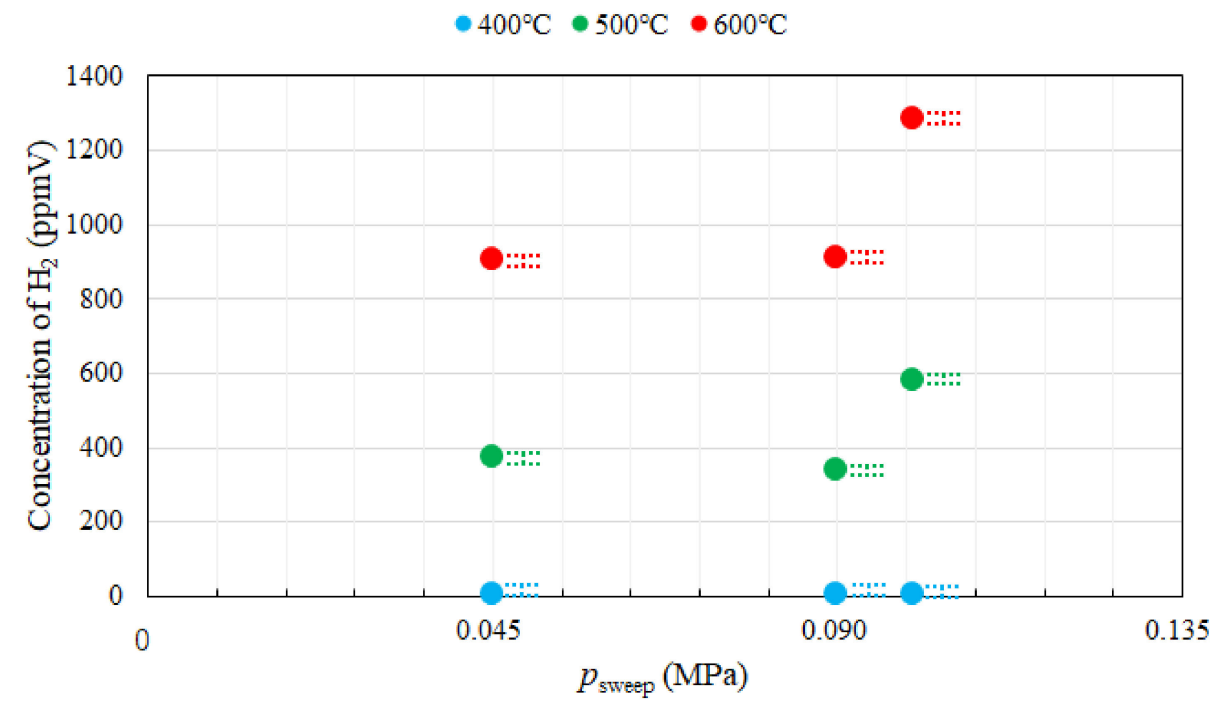

Figure 4. Impact of concentration of $\mathrm{H}_{2}$ at the outlet of the reaction chamber and $p_{\text {sweep }}$ with change in reaction temperature. $\left(\mathrm{CH}_{4}: \mathrm{CO}_{2}=1.5: 1\right)$.

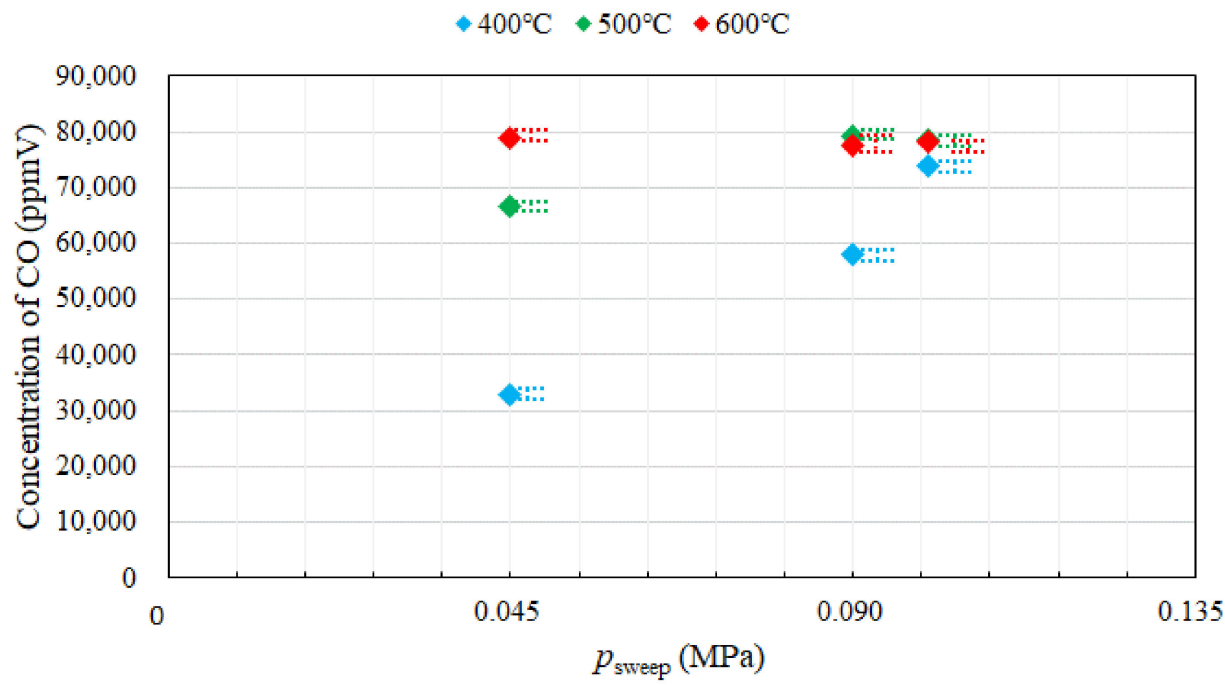

Figure 5. Impact of concentration of $\mathrm{CO}$ at the outlet of reaction chamber and $p_{\text {sweep }}$ with change in.reaction temperature. $\left(\mathrm{CH}_{4}: \mathrm{CO}_{2}=1.5: 1\right)$.

According to Figures 4 and 5, it is seen that the concentrations of $\mathrm{H}_{2}$ and $\mathrm{CO}$ increase with incases in reaction temperature. According to the theoretical kinetic studies [12,48], the reaction rates of $\mathrm{H}_{2}$ and $\mathrm{CO}$ increase with an increase in reaction temperature, resulting that the concentrations of $\mathrm{H}_{2}$ and $\mathrm{CO}$ increase. This is the same tendency observed in the experimental study using $\mathrm{Pd} / \mathrm{Ag} / \mathrm{Cu}$ membrane changing the reaction temperature from $350{ }^{\circ} \mathrm{C}$ to $700{ }^{\circ} \mathrm{C}$ [32]. Since reaction temperature is too low, it is believed that $\mathrm{H}_{2}$ is not produced at the reaction temperature of $400{ }^{\circ} \mathrm{C}$. In addition, it is observed from Figures 4 and 5 that the concentrations of $\mathrm{H}_{2}$ and $\mathrm{CO}$ under negative pressure conditions are lower than those under the atmosphere pressure condition, i.e., $p_{\text {sweep }}$ of $0.10 \mathrm{MPa}$. Since $\mathrm{H}_{2}$ flux thorough $\mathrm{Pd} / \mathrm{Cu}$ membrane is improved by increase in the pressure difference between reaction chamber and sweep chamber [45], it is thought that $\mathrm{H}_{2}$ is moved from the reaction chamber to the sweep chamber. Therefore, the concentration of $\mathrm{H}_{2}$ under negative pressure conditions is smaller than that under the atmosphere pressure condition. As to 
$\mathrm{CO}$, it is believed that the following reaction with $\mathrm{H}_{2} \mathrm{O}$, which is by-product in the reaction shown in Equation (3), might have been occurred [49]:

$$
\mathrm{CO}+\mathrm{H}_{2} \mathrm{O} \leftrightarrow \mathrm{CO}_{2}+\mathrm{H}_{2}
$$

In addition, the following reactions on carbon deposition are thought to be occurred $[32,50,51]$ :

$$
\begin{gathered}
2 \mathrm{CO} \rightarrow \mathrm{CO}_{2}+\mathrm{C} \\
\mathrm{CO}+\mathrm{H}_{2} \rightarrow \mathrm{H}_{2} \mathrm{O}+\mathrm{C}
\end{gathered}
$$

In this study, it is assumed that the concentration of $\mathrm{CO}$ decreases according to the combination of these reactions.

Table 2 lists the relationship between $\mathrm{H}_{2}, \mathrm{CO}$ selectivity and $p_{\text {sweep, }}$, respectively. Reaction temperature is varied to $400{ }^{\circ} \mathrm{C}, 500{ }^{\circ} \mathrm{C}$, or $600{ }^{\circ} \mathrm{C}$.

Table 2. Relationship between $\mathrm{H}_{2}, \mathrm{CO}$ selectivity and $p_{\text {sweep }}$ with change in reaction temperature.

\begin{tabular}{ccccccc}
\hline \multirow{2}{*}{$p_{\text {sweep }}(\mathbf{M P a})$} & \multicolumn{3}{c}{$\mathbf{H}_{\mathbf{2}}$ Selectivity (\%) } & \multicolumn{3}{c}{ CO Selectivity (\%) } \\
\cline { 2 - 6 } & $\mathbf{4 0 0}{ }^{\circ} \mathbf{C}$ & $\mathbf{5 0 0}^{\circ} \mathbf{C}$ & & $\mathbf{5 0 0}^{\circ} \mathbf{C}$ & $\mathbf{6 0 0}{ }^{\circ} \mathbf{C}$ \\
\hline 0.045 & 0 & 0.5 & 1.1 & 100 & 99.5 & 98.9 \\
0.090 & 0 & 0.4 & 1.2 & 100 & 99.6 & 98.8 \\
0.101 & 0 & 0.7 & 1.6 & 100 & 99.3 & 98.4 \\
\hline
\end{tabular}

According to Table 2, it is revealed that $\mathrm{CO}$ is produced mainly irrespective of $p_{\text {sweep }}$ changing reaction temperature. Since reaction temperature is relatively low even the reaction temperature of $600{ }^{\circ} \mathrm{C}$ and $\mathrm{H}_{2}$ selectivity increases with an increase in reaction temperature, especially over $600^{\circ} \mathrm{C}$ [32], high CO selectivity is noticed in this study.

Tables 3-5 list the relationship between $\mathrm{CH}_{4}$ conversion, $\mathrm{CO}_{2}$ conversion, $\mathrm{H}_{2}$ yield and $p_{\text {sweep }}$, respectively. The reaction temperature is varied to $400^{\circ} \mathrm{C}, 500{ }^{\circ} \mathrm{C}$, or $600^{\circ} \mathrm{C}$.

Table 3. Relationship between $\mathrm{CH}_{4}$ conversion and $p_{\text {sweep }}$ with change in reaction temperature.

\begin{tabular}{cccc}
\hline$p_{\text {sweep }}(\mathbf{M P a})$ & $\mathbf{4 0 0}{ }^{\circ} \mathbf{C}(\mathbf{\%})$ & $\mathbf{5 0 0}{ }^{\circ} \mathbf{C ~ ( \% )}$ & $\mathbf{6 0 0}{ }^{\circ} \mathbf{C ~ ( \% )}$ \\
\hline 0.045 & 0.002 & 0.129 & 0.303 \\
0.090 & 0.002 & 0.112 & 0.304 \\
0.101 & 0.003 & 0.193 & 0.429 \\
\hline
\end{tabular}

Table 4. Relationship between $\mathrm{CO}_{2}$ conversion and $p_{\text {sweep }}$ with change in reaction temperature.

\begin{tabular}{cccc}
\hline$p_{\text {sweep }} \mathbf{( M P a )}$ & $\mathbf{4 0 0}{ }^{\circ} \mathbf{C ~ ( \% )}$ & $\mathbf{5 0 0}{ }^{\circ} \mathbf{C ~ ( \% )}$ & $\mathbf{6 0 0}{ }^{\circ} \mathbf{C ~ ( \% )}$ \\
\hline 0.045 & 16.5 & 35.2 & 39.4 \\
0.090 & 29.3 & 40.1 & 38.9 \\
0.101 & 37.0 & 39.4 & 39.2 \\
\hline
\end{tabular}

Table 5. Relationship between $\mathrm{H}_{2}$ yield and $p_{\text {sweep }}$ with change in reaction temperature.

\begin{tabular}{cccc}
\hline$p_{\text {sweep }} \mathbf{( M P a )}$ & $\mathbf{4 0 0}{ }^{\circ} \mathbf{C ~ ( \% )}$ & $\mathbf{5 0 0}{ }^{\circ} \mathbf{C ~ ( \% )}$ & $\mathbf{6 0 0}{ }^{\circ} \mathbf{C ~ ( \% )}$ \\
\hline 0.045 & 0.0006 & 0.0322 & 0.0758 \\
0.090 & 0.0005 & 0.0281 & 0.0761 \\
0.101 & 0.0007 & 0.0483 & 0.1072 \\
\hline
\end{tabular}

According to Tables 3 and 5, it is seen that $\mathrm{CH}_{4}$ conversion and $\mathrm{H}_{2}$ yield are small. It is thought due to low concentration of $\mathrm{H}_{2}$ as shown in Figure 4. It is also seen from Tables 3 and 4 that $\mathrm{CO}_{2}$ conversion is larger compared to $\mathrm{CH}_{4}$ conversion irrespective of $p_{\text {sweep }}$ and reaction temperature, resulting from that the reaction shown by Equations (2) and (4) might be progressed well. 
3.2. Effect of Pressure of Sweep Gas on the Performance of Dry Reforming under Different Molar Ratios

Figures 6-8 compare the impact of concentrations of $\mathrm{CH}_{4}, \mathrm{CO}_{2}, \mathrm{H}_{2}$ and $\mathrm{CO}$ at the outlet of the reaction chamber with changing the molar ratio of $\mathrm{CH}_{4}: \mathrm{CO}_{2}$. The molar ratio of $\mathrm{CH}_{4}: \mathrm{CO}_{2}$ is varied to $1.5: 1,1: 1,1: 1.5$. In these figures, the reaction temperature is $500{ }^{\circ} \mathrm{C}$. In addition, the error bars are also shown in these figures.

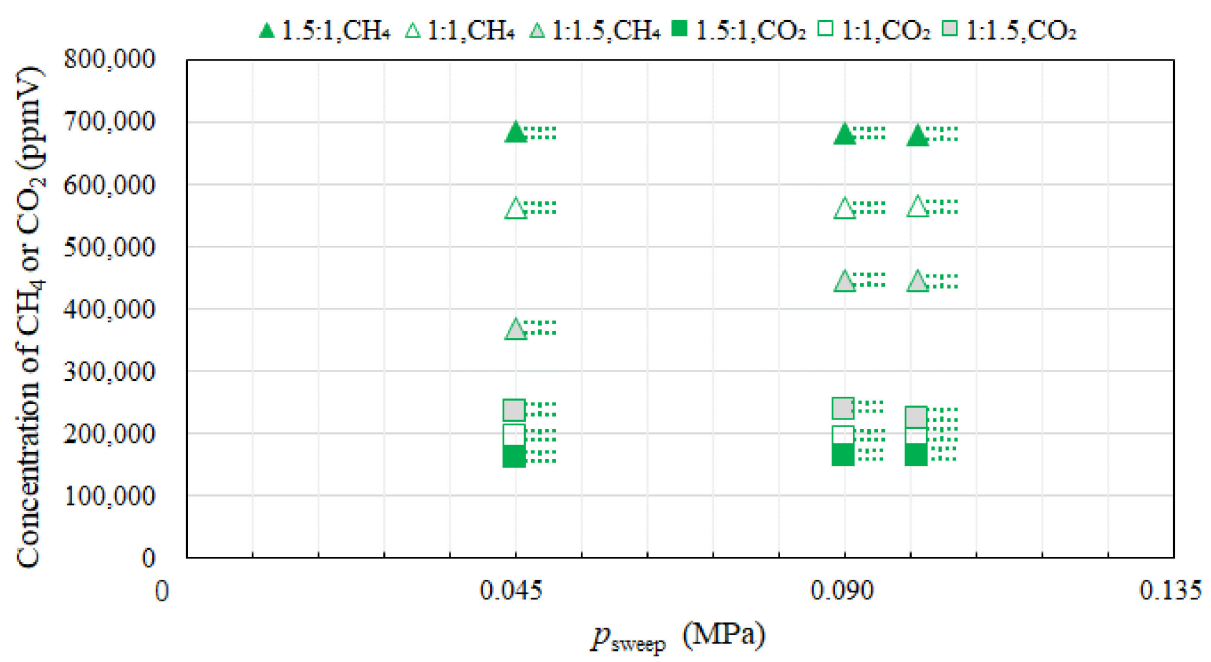

Figure 6. Impact of concentrations of $\mathrm{CH}_{4}$ and $\mathrm{CO}_{2}$ at the outlet of reaction chamber on $p_{\text {sweep }}$ with changing molar ratios of $\mathrm{CH}_{4}: \mathrm{CO}_{2}$.

According to Figure 6, it is found that the concentrations of $\mathrm{CH}_{4}$ and $\mathrm{CO}_{2}$ are changed with the molar ratio of $\mathrm{CH}_{4}: \mathrm{CO}_{2}$. In addition, it is seen from Figure 6 that the impact of $p_{\text {sweep }}$ on the concentrations of $\mathrm{CH}_{4}$ and $\mathrm{CO}$ is relatively small.

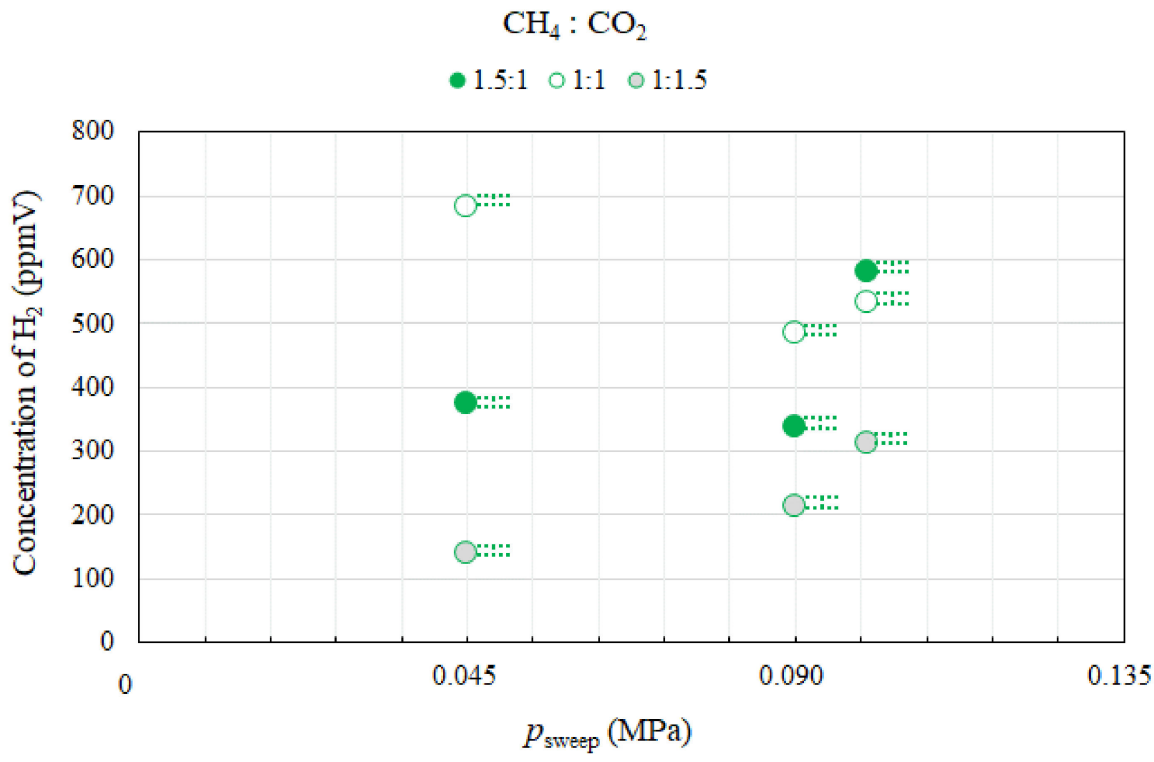

Figure 7. Impact of concentration of $\mathrm{H}_{2}$ at the outlet of reaction chamber and $p_{\text {sweep }}$ with changing molar ratios of $\mathrm{CH}_{4}: \mathrm{CO}_{2}$. 


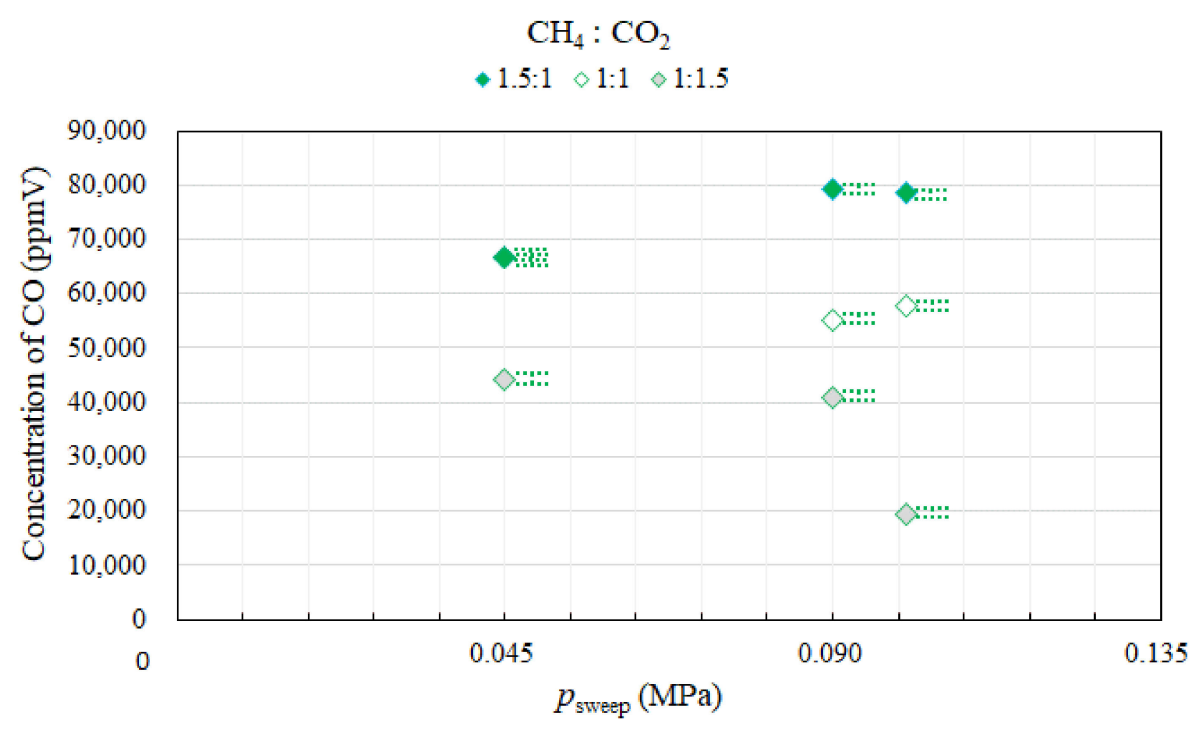

Figure 8. Relationship between concentration of $\mathrm{CO}$ at the outlet of reaction chamber and $p_{\text {sweep }}$ of with changing molar ratios of $\mathrm{CH}_{4}: \mathrm{CO}_{2}$.

It is seen from Figure 7 that the concentration of $\mathrm{H}_{2}$, in the case of the molar ratio of $\mathrm{CH}_{4}: \mathrm{CO}_{2}=1: 1$ is the highest among different molar ratio conditions. Since the molar ratio of $\mathrm{CH}_{4}: \mathrm{CO}_{2}=1: 1$ is the theoretical stoichiometric ratio according to Equation (1), it is believed that the reaction is progressed. Compared to the concentration of $\mathrm{H}_{2}$ in the case of the molar ratio of $\mathrm{CH}_{4}: \mathrm{CO}_{2}=1.5: 1$ with that in the case of the molar ratio of $\mathrm{CH}_{4}: \mathrm{CO}_{2}$ $=1: 1.5$, the former is higher than the latter. When the molar ratio of $\mathrm{CH}_{4}$ is larger, it is believed that Equation (3) is progressed well after $\mathrm{H}_{2} \mathrm{O}$ production by the reactions shown by Equations (2) and (4). In addition, it is observed from Figure 7 that the concentrations of $\mathrm{H}_{2}$ under negative pressure conditions are lower than those under the atmosphere pressure condition, except for the case of the molar ratio of $\mathrm{CH}_{4}: \mathrm{CO}_{2}=1: 1$. Since $\mathrm{H}_{2}$ flux thorough $\mathrm{Pd} / \mathrm{Cu}$ membrane is improved by increase in the pressure difference between reaction chamber and sweep chamber [45], it is thought that $\mathrm{H}_{2}$ is moved from the reaction chamber to the sweep chamber. Therefore, the concentration of $\mathrm{H}_{2}$ under negative pressure conditions is smaller than that under the atmosphere pressure condition. The amount of produced $\mathrm{H}_{2}$ might be large in the case of the molar ratio of $\mathrm{CH}_{4}: \mathrm{CO}_{2}=1: 1$, and the thickness of $\mathrm{Pd} / \mathrm{Cu}$ membrane might not be sufficient, resulting that $\mathrm{H}_{2}$ flux is not sufficient to extract $\mathrm{H}_{2}$ by $\mathrm{Pd} / \mathrm{Cu}$ membrane even $p_{\text {sweep }}$ at $0.045 \mathrm{MPa}$.

It is seen from Figure 8 that the concentration of $\mathrm{CO}$ in the case of the molar ratio of $\mathrm{CH}_{4}: \mathrm{CO}_{2}=1.5: 1$ is the highest among different molar ratio conditions. At the molar ratio of $\mathrm{CH}_{4}: \mathrm{CO}_{2}=1.5: 1$, it is believed that Equation (3) is progressed well after $\mathrm{H}_{2} \mathrm{O}$ production by the reactions shown by Equations (2) and (4). As a result, the concentration of $\mathrm{CO}$ increases in the case of the molar ratio of $\mathrm{CH}_{4}: \mathrm{CO}_{2}=1.5: 1$. Additionally, it is observed from Figure 8 that the concentration of $\mathrm{CO}$ in the case of the molar ratio of $\mathrm{CH}_{4}: \mathrm{CO}_{2}=1: 1.5$ is low at $p_{\text {sweep }}$ of $0.10 \mathrm{MPa}$. Since the performance of dry reforming of $\mathrm{CH}_{4}$ is worse, and it can not obtain the side-effect of $\mathrm{CO}$ production by $\mathrm{H}_{2}$ separation due to no pressure difference between reaction chamber and sweep chamber, it is believed that the concentration of $\mathrm{CO}$ is low under this condition.

Table 6 lists the relationship between $\mathrm{H}_{2}, \mathrm{CO}$ selectivity and $p_{\text {sweep }}$. The molar ratio of $\mathrm{CH}_{4}: \mathrm{CO}_{2}$ is varied to $1.5: 1,1: 1,1: 1.5$. In this table, the reaction temperature is $500{ }^{\circ} \mathrm{C}$. 
Table 6. Relationship between $\mathrm{H}_{2}, \mathrm{CO}$ selectivity and $p_{\text {sweep }}$ changing molar ratios of $\mathrm{CH}_{4}: \mathrm{CO}_{2}$.

\begin{tabular}{|c|c|c|c|c|c|c|}
\hline \multirow{2}{*}{$\begin{array}{l}p_{\text {sweep }} \\
(\mathrm{MPa})\end{array}$} & \multicolumn{3}{|c|}{$\mathrm{H}_{2}$ Selectivity (\%) } & \multicolumn{3}{|c|}{ CO Selectivity (\%) } \\
\hline & $\begin{array}{c}\mathrm{CH}_{4}: \mathrm{CO}_{2} \\
=1.5: 1\end{array}$ & $\begin{array}{c}\mathrm{CH}_{4}: \mathrm{CO}_{2} \\
=1: 1\end{array}$ & $\begin{array}{c}\mathrm{CH}_{4}: \mathrm{CO}_{2} \\
=1: 1.5\end{array}$ & $\begin{array}{c}\mathrm{CH}_{4}: \mathrm{CO}_{2} \\
=1.5: 1\end{array}$ & $\begin{array}{c}\mathrm{CH}_{4}: \mathrm{CO}_{2} \\
=1: 1\end{array}$ & $\begin{array}{c}\mathrm{CH}_{4}: \mathrm{CO}_{2} \\
=1: 1.5\end{array}$ \\
\hline 0.045 & 0.5 & 1.0 & 0.3 & 99.5 & 99.0 & 99.7 \\
\hline 0.090 & 0.4 & 0.9 & 0.5 & 99.6 & 99.1 & 99.5 \\
\hline 0.101 & 0.7 & 0.9 & 1.4 & 99.3 & 99.1 & 98.6 \\
\hline
\end{tabular}

According to Table 6, it is revealed that $\mathrm{CO}$ is produced mainly irrespective of $p_{\text {sweep }}$ changing reaction temperature. Since reaction temperature is relatively lower even the reaction temperature of $600{ }^{\circ} \mathrm{C}$ and $\mathrm{H}_{2}$ selectivity increases with an increase in reaction temperature, especially over $600{ }^{\circ} \mathrm{C}$ [32], high $\mathrm{CO}$ selectivity is obtained in this study.

Tables 7 and 8 list the relationship between $\mathrm{CH}_{4}, \mathrm{CO}_{2}$ conversion, $\mathrm{H}_{2}$ yield and $p_{\text {sweep }}$ changing moral ratio of $\mathrm{CH}_{4}: \mathrm{CO}_{2}$.

Table 7. Relationship between $\mathrm{CH}_{4}$ conversion, $\mathrm{CO}_{2}$ conversion and $p_{\text {sweep }}$ changing molar ratios of $\mathrm{CH}_{4}: \mathrm{CO}_{2}$.

\begin{tabular}{|c|c|c|c|c|c|c|}
\hline \multirow{2}{*}{$\begin{array}{r}P_{\text {sweep }} \\
(\mathrm{MPa})\end{array}$} & \multicolumn{3}{|c|}{$\mathrm{CH}_{4}$ Conversion $(\%)$} & \multicolumn{3}{|c|}{$\mathrm{CO}_{2}$ Conversion $(\%)$} \\
\hline & $\begin{array}{c}\mathrm{CH}_{4}: \mathrm{CO}_{2} \\
=1.5: 1\end{array}$ & $\begin{array}{c}\mathrm{CH}_{4}: \mathrm{CO}_{2} \\
=1: 1\end{array}$ & $\begin{array}{c}\mathrm{CH}_{4}: \mathrm{CO}_{2} \\
=1: 1.5\end{array}$ & $\begin{array}{c}\mathrm{CH}_{4}: \mathrm{CO}_{2} \\
=1.5: 1\end{array}$ & $\begin{array}{c}\mathrm{CH}_{4}: \mathrm{CO}_{2} \\
=1: 1\end{array}$ & $\begin{array}{c}\mathrm{CH}_{4}: \mathrm{CO}_{2} \\
=1: 1.5\end{array}$ \\
\hline 0.045 & 0.129 & 0.231 & 0.047 & 35.2 & 33.5 & 22.2 \\
\hline 0.090 & 0.112 & 0.162 & 0.072 & 40.1 & 27.8 & 20.6 \\
\hline 0.101 & 0.193 & 0.178 & 0.105 & 39.4 & 29.0 & 9.85 \\
\hline
\end{tabular}

Table 8. Relationship between $\mathrm{H}_{2}$ yield and $p_{\text {sweep }}$ changing molar ratios of $\mathrm{CH}_{4}: \mathrm{CO}_{2}$.

\begin{tabular}{cccc}
\hline & \multicolumn{3}{c}{$\mathrm{H}_{\mathbf{2}}$ Yield (\%) } \\
\cline { 2 - 4 } $\boldsymbol{P}_{\text {sweep }}(\mathrm{MPa})$ & $\begin{array}{c}\mathrm{CH}_{\mathbf{4}}: \mathrm{CO}_{\mathbf{2}} \\
\mathbf{\mathbf { 1 . 5 } : \mathbf { 1 }}\end{array}$ & $\begin{array}{c}\mathrm{CH}_{\mathbf{4}}: \mathrm{CO}_{\mathbf{2}} \\
=\mathbf{1 : 1}\end{array}$ & $\begin{array}{c}\mathrm{CH}_{\mathbf{4}}: \mathbf{C O}_{\mathbf{2}} \\
\mathbf{1}: \mathbf{1 . 5}\end{array}$ \\
\hline 0.045 & 0.0322 & 0.0578 & 0.0117 \\
0.090 & 0.0281 & 0.0405 & 0.0180 \\
0.101 & 0.0483 & 0.0444 & 0.0262 \\
\hline
\end{tabular}

According to Tables 7 and 8 , it is seen that the $\mathrm{CH}_{4}$ conversion and $\mathrm{H}_{2}$ yield is the highest in the case of $\mathrm{CH}_{4}: \mathrm{CO}_{2}=1: 1$, respectively. It is because the concentration of $\mathrm{H}_{2}$ is the highest in the case of $\mathrm{CH}_{4}: \mathrm{CO}_{2}=1: 1$, as shown in Figure 7. In addition, it is found from Table 7 that $\mathrm{CO}_{2}$ conversion is higher than $\mathrm{CH}_{4}$ conversion irrespective of molar ratio of $\mathrm{CH}_{4}: \mathrm{CO}_{2}$. Since the reactions shown by Equations (2) and (4) might be progressed well, this tendency is obtained.

\subsection{Effect of Pressure of Sweep Gas on $\mathrm{H}_{2}$ Flux from Reaction Chamber to Sweep Chamber}

Figure 9 compares the impact of concentrations of $\mathrm{H}_{2}$ at the outlet of the sweep chamber with changing reaction temperature. The reaction temperature is varied to $400{ }^{\circ} \mathrm{C}$, $500{ }^{\circ} \mathrm{C}$, or $600{ }^{\circ} \mathrm{C}$. The error bars are also shown in this figure. It is seen from Figure 9 that the concentration of $\mathrm{H}_{2}$ increases with a decrease in $p_{\text {sweep }}$ irrespective of reaction temperature as expected. This is due to an increase in $\mathrm{H}_{2}$ flux depending on the pressure difference between the reaction chamber and sweep chamber. In addition, the concentration of $\mathrm{H}_{2}$ is the highest at the reaction temperature of $500{ }^{\circ} \mathrm{C}$ and $p_{\text {sweep }}$ of $0.045 \mathrm{MPa}$. The reason is discussed as follows: 


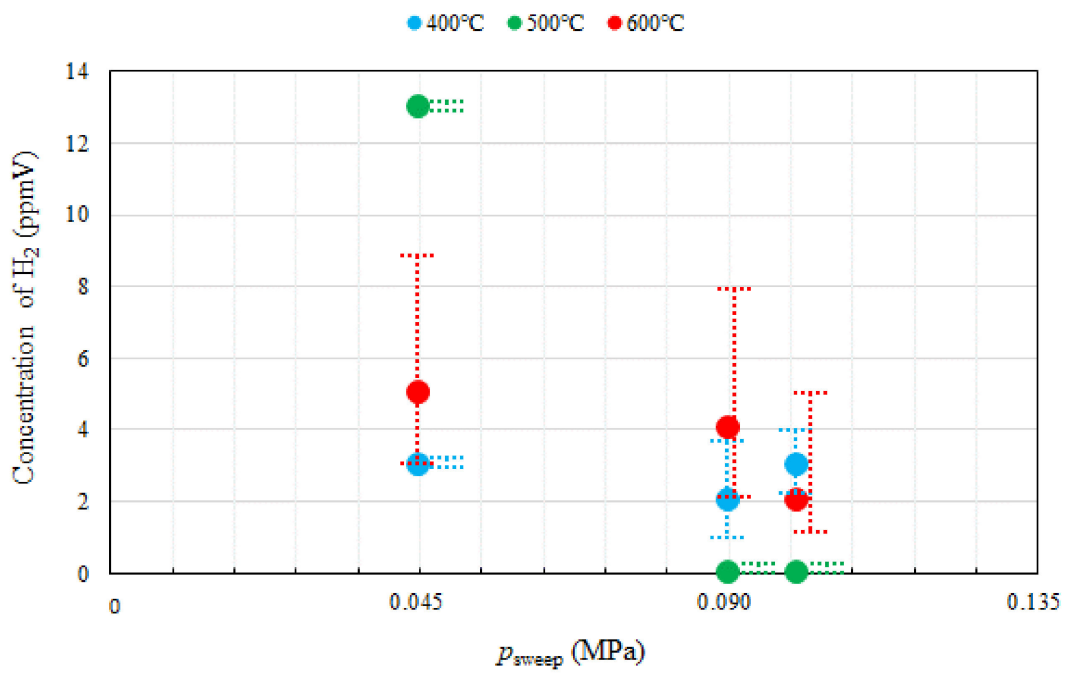

Figure 9. Impact of concentration of $\mathrm{H}_{2}$ at the outlet of sweep chamber with $p_{\text {sweep }}$ and reaction temperature.

In this study, the pressures of reaction chamber and sweep chamber have been measured by pressure sensors. The permeation flux through $\mathrm{Pd} / \mathrm{Cu}$ membrane is calculated using the measured pressures of reaction chamber and sweep chamber as follows [52]:

$$
J=\frac{\operatorname{Pe}\left(\sqrt{p_{\text {react }}}-\sqrt{p_{\text {sweep }}}\right)}{\delta}
$$

where $J$ is the permeation flux $\left(\mathrm{mol} /\left(\mathrm{m}^{2} \cdot \mathrm{s}\right)\right), P e$ is the permeability and it is an inherent property of membrane $\left(\mathrm{mol} /\left(\mathrm{m} \cdot \mathrm{s} \cdot \mathrm{Pa}^{0.5}\right)\right), p_{\text {react }}$ is the pressure of reaction chamber $(\mathrm{MPa})$, $p_{\text {sweep }}$ is the pressure of sweep chamber (MPa) and $\delta$ is the thickness of membrane (m). Pe of $\mathrm{Pd} / \mathrm{Cu}$ membrane, used in this study, is listed in Table 9.

Table 9. Pe of Pd/Cu membrane used in this study [53].

\begin{tabular}{cc}
\hline Temperature $\left({ }^{\circ} \mathbf{C}\right)$ & $\boldsymbol{P e}\left(\mathbf{m o l} /\left(\mathbf{m} \cdot \mathbf{s} \cdot \mathbf{P a}^{\mathbf{0 . 5}}\right)\right)$ \\
\hline 400 & $1.0 \times 10^{-8}$ \\
500 & $5.0 \times 10^{-9}$ \\
600 & $1.0 \times 10^{-9}$ \\
\hline
\end{tabular}

Figure 10 shows the impact of $J$ and $p_{\text {sweep }}$ with changing reaction temperature and molar ratio of $\mathrm{CH}_{4}: \mathrm{CO}_{2}$.

It is observed from Figure 10 that $J$ increases with decrease in $p_{\text {sweep }}$ irrespective of reaction temperature and molar ratio of $\mathrm{CH}_{4}: \mathrm{CO}_{2}$. It is due to an increase in the pressure difference between the reaction chamber and the sweep chamber. Additionally, it is found that $J$ decreases with an increase in reaction temperature irrespective of $p_{\text {sweep }}$ and molar ratio of $\mathrm{CH}_{4}: \mathrm{CO}_{2}$. According to Table 9, Pe of Pd/Cu membrane decreases with an increase in temperature, resulting that $J$ decreases with an increase in reaction temperature.

In this study, $J$ is the highest at the reaction temperature of $400{ }^{\circ} \mathrm{C}$, while the amount of produced $\mathrm{H}_{2}$ is the smallest at the reaction temperature of $400{ }^{\circ} \mathrm{C}$ due to a low kinetic production rate depending on temperature [54]. On the other hand, the amount of produced $\mathrm{H}_{2}$ is the highest at the reaction temperature of $600^{\circ} \mathrm{C}$, while $J$ is the lowest at the reaction temperature of $600{ }^{\circ} \mathrm{C}$. Considering these tendencies, it can be thought that the reaction temperature of $500^{\circ} \mathrm{C}$ is the optimum temperature, as shown in Figure 9. 


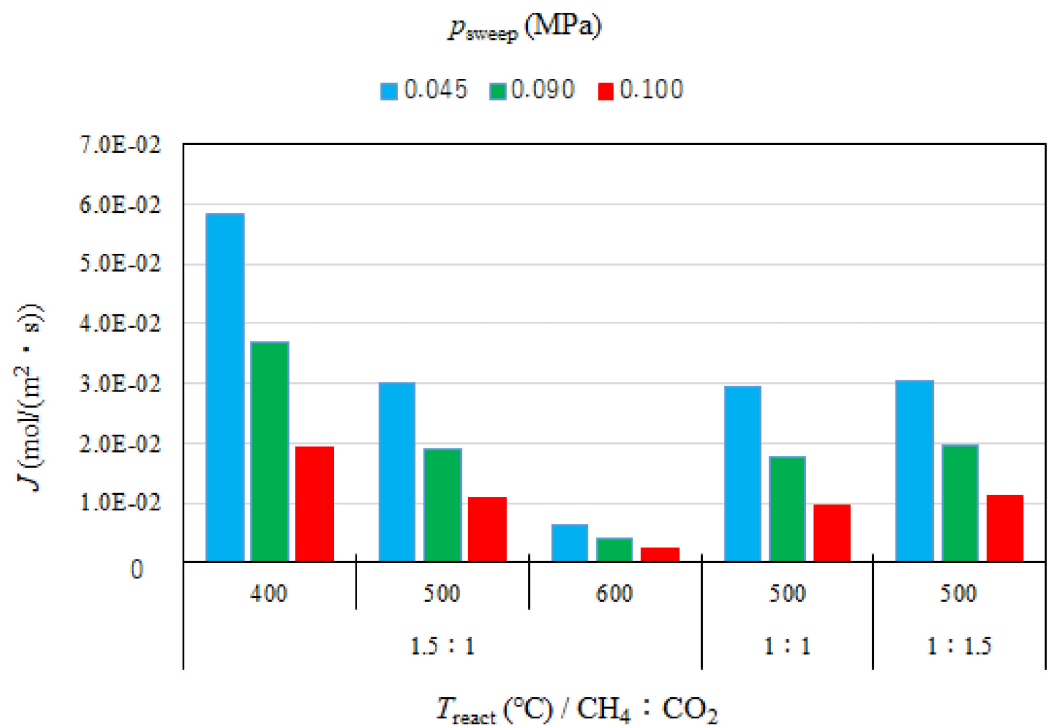

Figure 10. Impact of permeation flux with $p_{\text {sweep, }}$ reaction temperature and molar ratios of $\mathrm{CH}_{4}: \mathrm{CO}_{2}$.

In this study, the performance of $\mathrm{CH}_{4}$ dry reforming has not been high. According to the previous review paper on $\mathrm{CH}_{4}$ dry reforming [55], $\mathrm{CH}_{4}$ and $\mathrm{CO}_{2}$ conversion were over $80 \%$, though the reaction temperature was over $700{ }^{\circ} \mathrm{C}$ using several alloy catalysts, such as $\mathrm{Ni} / \mathrm{MgO}, \mathrm{Ni} / \mathrm{Ce}_{0.8} \mathrm{Zr}_{0.2} \mathrm{O}_{2}, \mathrm{Ni} / \mathrm{Co}$ and $\mathrm{Ni} / \mathrm{CeO}_{2}$. The previous study also reported that not only $\mathrm{CH}_{4}$ conversion, but also $\mathrm{H}_{2}$ yield increased with an increase in the reaction temperature from $550{ }^{\circ} \mathrm{C}$ to $750{ }^{\circ} \mathrm{C}$ [56]. In addition, it was also reported that $\mathrm{H}_{2}$ and $\mathrm{CO}$ yield increased with an increase in the reaction temperature from $450{ }^{\circ} \mathrm{C}$ to $700{ }^{\circ} \mathrm{C}$, especially over $600{ }^{\circ} \mathrm{C}$ [32]. $\mathrm{H}_{2}$ and $\mathrm{CO}$ yield attained at $30 \%$ and $45 \%$, respectively at $700{ }^{\circ} \mathrm{C}$ [32]. Though the previous studies exhibited the better performance compared to this study, the reaction temperature is higher than this study. Reaction temperature is thought to be one essential parameter to decide the performance of $\mathrm{CH}_{4}$ dry reforming, resulting that this study will investigate the higher reaction temperature condition in the near future. According to the numerical kinematic study on $\mathrm{CH}_{4}$ steam reforming [57], which is one of the conventional approaches for $\mathrm{H}_{2}$ production, the $\mathrm{CH}_{4}$ conversion was approximately $65 \%$ at the reaction temperature of $650{ }^{\circ} \mathrm{C}$ and the pressure of $3.5 \mathrm{MPa}$ with $\mathrm{Ni} / \mathrm{Al}_{2} \mathrm{O}_{3}$ catalyst in a fixed bed reactor. In addition, the other experimental and numerical previous study on $\mathrm{CH}_{4}$ steam reforming over $\mathrm{NiO} / \mathrm{Al}_{2} \mathrm{O}_{3}$ catalyst [58] reported that the rate of $\mathrm{CO}$ formation increased with an increase in reaction temperature and almost all the $\mathrm{CH}_{4}$ was converted to $\mathrm{CO}$ and $\mathrm{H}_{2}$ at the reaction temperature of $800{ }^{\circ} \mathrm{C}$. At $800{ }^{\circ} \mathrm{C}$, $\mathrm{CH}_{4}$ conversion, $\mathrm{H}_{2}$ production rate and $\mathrm{CO}$ selectivity were $92.28 \%, 3.34 \%$ and $99 \%$, respectively. It can be also known from these references on the conventional approach for $\mathrm{H}_{2}$ production that reaction temperature is an important parameter to improve the performance of $\mathrm{H}_{2}$ production.

It is necessary to improve the performance of $\mathrm{CH}_{4}$ dry reforming from the view point of reaction kinetics and $\mathrm{H}_{2}$ separation. Though only pure $\mathrm{Ni}$ catalyst has been investigated in this study, Ni-based alloy catalysts, such as $\mathrm{Ni} / \mathrm{Ce}$ [6], $\mathrm{Ni} / \mathrm{La}$ [6] and $\mathrm{Ni} / \mathrm{ZnO}^{-} \mathrm{Al}_{2} \mathrm{O}_{3}$ [17] exhibited the better performance, and they are promising candidate catalysts for further studies. In addition, the characterization of $\mathrm{H}_{2}$ separation membrane, such as composition, thickness, and metal type, is important to improve the efficiency of $\mathrm{H}_{2}$ separation. Since this study has investigated one type of $\mathrm{H}_{2}$ separation membrane only, i.e., $\mathrm{Pd} / \mathrm{Cu}$ alloy membrane ( $\mathrm{Cu}$ of $40 \mathrm{wt} \%$ ) whose thickness is $60 \mu \mathrm{m}$, the different composition and thinner membrane will also be investigated in the near future.

In addition, the control of pressure difference between reaction chamber and sweep chamber is important to improve the performance of $\mathrm{H}_{2}$ separation membrane. The numerical analysis on biogas dry reforming membrane reactor reported that the system 
efficiency, which was defined by the ratio of $\mathrm{H}_{2}$ energy output to biogas and auxiliaries energy inputs, increased with an increase in the pressure difference between reaction chamber and sweep chamber, and $\mathrm{H}_{2}$ production efficiency was attained around $69 \%$ at the pressure difference of 20 bar $(=0.2 \mathrm{MPa})$ [59]. Since the pressure difference provided by this study is up to $0.055 \mathrm{MPa}$, it might be desirable to investigate the higher pressure difference in order to improve the proposed membrane reactor.

Finally, this study suggests optimizing the catalyst, $\mathrm{H}_{2}$ separation membrane and operation condition in order to obtain a progress compared to other similar studies.

\section{Conclusions}

This study has studied the effect of $p_{\text {sweep }}$ on the performance of biogas dry reforming. This study has investigated the effect changing the reaction temperature from $400{ }^{\circ} \mathrm{C}$ to $600{ }^{\circ} \mathrm{C}$, and the molar ratio of $\mathrm{CH}_{4}: \mathrm{CO}_{2}$ by $1.5: 1,1: 1$ and 1:1.5, where the molar ratio of $\mathrm{CH}_{4}: \mathrm{CO}_{2}=1.5: 1$ simulates a biogas. As a result, the following conclusions are drawn from the obtained results:

(i) Under the condition of the molar ratio of $\mathrm{CH}_{4}: \mathrm{CO}_{2}=1.5: 1$ changing the reaction temperature by $400{ }^{\circ} \mathrm{C}, 500{ }^{\circ} \mathrm{C}, 600{ }^{\circ} \mathrm{C}$, the impact of $p_{\text {sweep }}$ on concentrations of $\mathrm{CH}_{4}$ and $\mathrm{CO}$ at the outlet of reaction chamber is negligible. It is concluded that the concentrations of $\mathrm{H}_{2}$ and $\mathrm{CO}$ at the outlet of reaction chamber increase with incase in the reaction temperature. It is revealed that the concentration of $\mathrm{H}_{2}$ at the outlet of reaction chamber, under negative pressure conditions, is smaller than that under the atmosphere pressure condition. High $\mathrm{CO}$ selectivity is obtained, while $\mathrm{H}_{2}$ selectivity is low.

(ii) Under the condition of the reaction temperature of $500{ }^{\circ} \mathrm{C}$ changing molar ratio of $\mathrm{CH}_{4}: \mathrm{CO}_{2}$, the highest concentration of $\mathrm{H}_{2}$ at the outlet of reaction chamber is obtained at the molar ratio of $\mathrm{CH}_{4}: \mathrm{CO}_{2}=1: 1$. In addition, the concentrations of $\mathrm{H}_{2}$ at the outlet of reaction chamber under negative pressure conditions are lower than those under the atmosphere pressure condition, except for the case of the molar ratio of $\mathrm{CH}_{4}: \mathrm{CO}_{2}=1: 1$. The concentration of $\mathrm{CO}$ at the outlet of reaction chamber is the highest in the case of the molar ratio of $\mathrm{CH}_{4}: \mathrm{CO}_{2}=1.5: 1$. High $\mathrm{CO}$ selectivity is obtained, while $\mathrm{H}_{2}$ selectivity is low.

(iii) $\mathrm{CO}_{2}$ conversion is larger compared to $\mathrm{CH}_{4}$ conversion irrespective of $p_{\text {sweep }}$, reaction temperature and molar ratio of $\mathrm{CH}_{4}: \mathrm{CO}_{2} \cdot \mathrm{CH}_{4}$ conversion and $\mathrm{H}_{2}$ yield is the highest in the case of $\mathrm{CH}_{4}: \mathrm{CO}_{2}=1: 1$, respectively.

(iv) The concentration of $\mathrm{H}_{2}$ at the outlet of sweep chamber is the highest at the reaction temperature of $500{ }^{\circ} \mathrm{C}$ and $p_{\text {sweep }}$ of $0.045 \mathrm{MPa}$. It is due to the balance between the permeation flux and reaction kinetics.

According to the investigation by this study, it is necessary to improve the performance of $\mathrm{CH}_{4}$ dry reforming from the view point of reaction kinetics and $\mathrm{H}_{2}$ separation. Ni-based alloy catalyst is a promising catalyst in order to improve the performance of $\mathrm{CH}_{4}$ dry reforming. In addition, it is important to clarify the impact of the characterization of $\mathrm{H}_{2}$ separation membrane, such as composition, thickness, and metal type, on the efficiency of $\mathrm{H}_{2}$ separation. Furthermore, it is also important to control the pressure difference between reaction chamber and sweep chamber in order to improve the performance of the $\mathrm{H}_{2}$ separation membrane.

Author Contributions: Conceptualization, A.N.; experiment and data curation, T.T. and S.O.; writing—original draft preparation, A.N.; writing—review and editing, M.L.K. All authors have read and agreed to the published version of the manuscript.

Funding: This research was funded by the joint research program of the Institute of Materials and Systems for Sustainability, Nagoya University and the Tatematsu Foundation, Japan.

Institutional Review Board Statement: Not applicable.

Informed Consent Statement: Not applicable. 
Data Availability Statement: The data presented in this study are openly available.

Conflicts of Interest: The authors declare no conflict of interest.

\section{References}

1. Tinnirello, M.; Papurello, D.; Santarelli, M.; Fiorilli, S. Thermal activation of digested sewage sludges for carbon dioxide removal from biogas. Fuels 2020, 1, 30-46. [CrossRef]

2. Kuan, C.Y.; Neng, M.L.Y.; Chan, Y.B.; Sim, Y.L.; Strothers, J.; Pratt, L.M. Thermal transformation of plan waste to high-quality hydrocarbon fuel. Fuels 2020, 1, 2-14. [CrossRef]

3. Karatza, D.; Konstantopoulos, C.; Chianese, S.; Diplas, S.; Svec, P.; Hristoforou, E.; Musmarra, D. Hydrogen production through water splitting at low temperature over $\mathrm{Fe}_{3} \mathrm{O}_{4}$ pellet: Effects of electric power, magnetic field, and temperature. Fuel Process. Technol. 2021, 211, 106606. [CrossRef]

4. Guo, S.; Li, X.; Li, J.; Wei, B. Boosting photocatalytic hydrogen production from water by photothermally induced biphase systems. Nat. Commun. 2021, 12, 1-10. [CrossRef]

5. Vinvent, I.; Lee, E.C.; Kim, H.M. Comprehensive impedance investigation of low-cost anion exchange membrane electrolysis for large-scale hydrogen production. Sci. Rep. 2021, 11, 1-12. [CrossRef]

6. Kalai, D.Y.; Stangeland, K.; Jin, Y.; Tucho, W.M.; Yu, Z. Biogas dry reforming for syngas production on La promoted hydrotalcitederived Ni catalyst. Int. J. Hydrog. Energy 2018, 43, 19438-19450. [CrossRef]

7. World Bioenergy Association. Global Bioenergy Statistics. Available online: https://worldbioenergy.org./global-bioenergystatistics (accessed on 23 March 2021).

8. The Japan Gas Association. Available online: https:/ /www.gas.or.jp/gas-life/biomass/ (accessed on 23 March 2021).

9. Foo, S.Y.; Cheng, C.K.; Nguyen, T.H.; Adesina, A.A. Kinetic study of methane $\mathrm{CO}_{2}$ reforming on Co-Ni/Al $\mathrm{O}_{3}$ and Ce-Co$\mathrm{Ni} / \mathrm{Al}_{2} \mathrm{O}_{3}$ catalysts. Catal. Today 2011, 164, 221-226. [CrossRef]

10. Bobrova, L.N.; Bobin, A.S.; Mezentseva, N.V.; Sadykov, V.A.; Thybaut, J.W.; Marin, G.B. Kinetic assessment of dry reforming of methane on $\mathrm{Pt}+\mathrm{Ni}$ containing composite of fluorite-like structure. Appl. Catal. B Environ. 2016, 182, 513-524. [CrossRef]

11. Park, N.; Park, M.J.; Baek, S.C.; Ha, K.S.; Lee, Y.J.; Kwak, G.; Park, H.G.; Jun, K.W. Modeling and optimization of the mixed reforming of methane: Maximizing $\mathrm{CO}_{2}$ utilization for non-equilibrated reaction. Fuel 2014, 115, 357-365. [CrossRef]

12. Ozkara-Aydinoglu, S.; Aksoylu, A.E. A comparative study on the kinetics of carbon dioxide reforming of methane over Pt$\mathrm{Ni} / \mathrm{Al}_{2} \mathrm{O}_{3}$ catalyst: Effect of Pt/Ni ratio. Chem. Eng. J. 2013, 215-216, 542-549. [CrossRef]

13. Li, K.; He, F.; Yu, H.; Wang, Y.; Wu, Z. Theoretical study on the reaction mechanism of carbon dioxide reforming of methane on La and $\mathrm{La}_{2} \mathrm{O}_{3}$ modified $\mathrm{Ni}$ (1 11 1) surface. J. Catal. 2018, 364, 248-261. [CrossRef]

14. Elsayed, N.H.; Roberts, N.R.M.; Joseph, B.; Kuhn, J.N. Comparison of Pd-Ni-Mg/Ceria-Zirconia and Pt-Ni-Mg/Ceria-Zirconia catalysts for syngas production via low temperature forming of model biogas. Top. Catal. 2016, 59, 138-146. [CrossRef]

15. Shang, Z.; Li, S.; Li, L.; Liu, G.; Liang, X. Highly active and stable alumina supported nickel nanoparticle catalysts for dry reforming of methane. Appl. Catal. B Environ. 2017, 201, 302-309. [CrossRef]

16. Omoregbe, O.; Danh, H.T.; Nguyen-Huy, C.; Setiabudi, H.D.; Abidin, S.Z.; Truong, Q.D.; Vo, D.V.N. Syngas production from methane dry reforming over Ni/SBA-15 catalyst: Effect of operating parameters. Int. J. Hydrog. Energy 2017, 42, 11283-11294. [CrossRef]

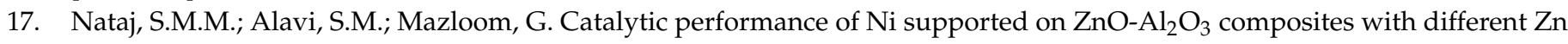
content in methane dry reforming. J. Chem. Technol. Biotechnol. 2019, 94, 1305-1314. [CrossRef]

18. Yan, X.; Hu, T.; Liu, P.; Li, S.; Zhao, B.; Zhang, Q.; Jiao, W.; Chen, S.; Wang, P.; Lu, J.; et al. Highly efficient and stable Ni/CeO ${ }_{2}-\mathrm{SiO}_{2}$ catalyst for dry reforming of methane: Effect of interfacial structure of $\mathrm{Ni} / \mathrm{CeO}_{2}$ on $\mathrm{SiO}_{2}$. Appl. Catal. B Environ. 2019, 246, 221-231. [CrossRef]

19. Zhang, M.; Zhang, J.; Wu, Y.; Pan, J.; Zhang, Q.; Tan, Y.; Han, Y. Insight into the effects of the oxygen species over Ni/ZrO 2 catalyst surface on methane reforming with carbon dioxide. Appl. Catal. B Environ. 2019, 244, 427-437. [CrossRef]

20. Park, J.H.; Heo, I.; Chang, T.S. Dry reforming of methane over Ni-substituted CaZrNiOx catalyst prepared by the homogeneous deposition method. Catal. Commun. 2019, 120, 1-5. [CrossRef]

21. Hossain, M.A.; Ayodele, B.V.; Cheng, C.K.; Khan, M.R. Optimization of renewable hydrogen-rich syngas production from catalytic reforming of greenhouse gases $\left(\mathrm{CH}_{4}\right.$ and $\left.\mathrm{CO}_{2}\right)$ over calcium iron oxide supported nickel catalyst. J. Energy Inst. 2019, 92, 177-194. [CrossRef]

22. Rosha, P.; Mohapatra, S.K.; Mahla, S.K.; Dhir, A. Biogas reforming for hydrogen enrichment by ceria decorated over nickel catalyst supported on titania and alumina. Int. J. Hydrog. Energy 2018, 43, 21246-21255. [CrossRef]

23. Rosha, P.; Mohapatra, S.K.; Mahla, S.K.; Dhir, A. Hydrogen enrichment of biogas via dry and authothermal-dry reforming with pure nickel (Ni) nanoparticle. Energy 2019, 172, 733-739. [CrossRef]

24. Rosha, P.; Mohapatra, S.K.; Mahla, S.K.; Dhir, A. Catalytic reforming of synthetic biogas for hydrogen enrichment over Ni supported on $\mathrm{ZnO}-\mathrm{CeO}_{2}$ mixed catalyst. Biomass Bioenergy 2019, 125, 70-78. [CrossRef]

25. Schiaroli, N.; Lucarelli, C.; Luna, G.S.; Fornasari, G.; Vaccari, A. Ni-based catalysts to produce synthesis gas by combined reforming of clean biogas. Appl. Catal. A Gen. 2019, 582, 117087. [CrossRef]

26. Lyu, L.; Han, Y.; Ma, Q.; Makpal, S.; Sun, J.; Gao, X.; Zhang, J.; Fan, H.; Zhao, T.S. Fabrication of Ni-based bimodal porous catalyst for dry reforming of methane. Catalysts 2020, 10, 1220. [CrossRef] 
27. Omran, A.; Yoon, S.H.; Khan, M.; Ghouri, M.; Chatla, A.; Elbashir, N. Mechanistic insights for dry reforming of methane on $\mathrm{Cu} / \mathrm{Ni}$ bimetallic catalysts: DFT-assisted microkinetic analysis for coke resistance. Catalysts 2020, 10, 1043. [CrossRef]

28. Anzelmo, B.; Wilcox, J.; Liguori, S. Natural gas stream reforming reaction at low temperature and pressure conditions for hydrogen production via Pd/PSS methane reactor. J. Membr. Sci. 2017, 522, 343-350. [CrossRef]

29. Yan, Y.; Cui, Y.; Zhang, J.; Chen, Y.; Tang, Q.; Lin, C. Experimental investigation of methane auto-thermal reforming in hydrogenpermeable membrane reactor for pure hydrogen production. Int. J. Hydrog. Energy 2016, 41, 13069-13076. [CrossRef]

30. Dolan, M.; Beath, A.; Hla, S.; Way, J.; Abu El Hawa, H. An experimental and techno-economic assessment of solar reforming for $\mathrm{H}_{2}$ production. Int. J. Hydrog. Energy 2016, 41, 14583-14595. [CrossRef]

31. Brunetti, A.; Fontananova, E. $\mathrm{CO}_{2}$ conversion by membrane reactors. J. Nanosci. Nanotechnol. 2019, 19, 3124-3134. [CrossRef]

32. Sumrunronnasak, S.; Tantayanon, S.; Kiatgamolchai, S.; Sukonket, T. Improved hydrogen production from dry reforming reaction using a catalytic packed-bed membrane reactor with Ni-based catalyst and dense PdAgCu alloy membrane. Int. J. Hydrog. Energy 2016, 41, 2621-2630. [CrossRef]

33. Duran, P.; Sanz-Martinez, A.; Soler, J.; Manendez, M.; Herguido, J. Pure hydrogen from biogas: Intensified methane dry reforming in a two-zone fluidized bed reactor using permselective membranes. Chem. Eng. J. 2019, 370, 772-781. [CrossRef]

34. Bosko, M.L.; Munera, J.F.; Lombardo, E.A.; Cornaglia, L.M. Dry reforming of methane in membrane reactors using Pd and Pd-Ag composite membranes on a NaA zeolite modified porous stainless steel support. J. Membr. Sci. 2010, 364, 17-26. [CrossRef]

35. Munera, J.; Faroldi, B.; Fruits, E.; Lombardo, E.; Cornaglia, L.; Carrazan, S.G. Supported Rh nanoparticles on CaO-SiO 2 binary systems for the reforming of methane by carbon dioxide in membrane reactors. Appl. Catal. A Gen. 2014, 474, 114-124. [CrossRef]

36. Simakov, D.S.A.; Roman-Leshkov, Y. Highly efficient methane reforming over a low-loading $\mathrm{Ru} /-\mathrm{Al}_{2} \mathrm{O}_{3}$ catalyst in a Pd-Ag membrane reactor. AICHE J. 2018, 64, 3101-3108. [CrossRef]

37. Liu, J.; Bellini, S.; Nooijer, N.C.A.; Sun, Y.; Tanaka, D.A.P.; Tang, C.; Li, H.; Gallucci, F.; Caravella, A. Hydrogen permeation and stability in ultra-thin Pd-Ru supported membrane. Int. J. Hydrog. Energy 2020, 45, 7455-7467. [CrossRef]

38. Fontana, A.D.; Faroldi, B.; Cornaglia, L.M.; Tarditi, A.M. Development of catalytic membranes over PdAu selective films for hydrogen production through the dry reforming of methane. Mol. Catal. 2020, 481, 100643. [CrossRef]

39. Jia, H.; Xu, H.; Sheng, X.; Yang, X.; Shen, W.; Goldbach, A. High-temperature ethanol steam reforming in PdCu membrane reactor. J. Membr. Sci. 2020, 605, 118083. [CrossRef]

40. Roa, F.; Way, D. Influence of alloy composition and membrane fabrication on the pressure dependence of the hydrogen flux of palladium-copper membranes. Ind. Eng. Chem. Res. 2003, 42, 5827-5835. [CrossRef]

41. Garcia-Garcia, F.R.; Soria, M.A.; Mateos-Pedero, C.; Guerrero-Ruiz, A.; Odriguez-Ramos, I.; Li, K. Dry reforming of methane using Pd-based membrane reactors fabricated from different substrates. J. Membr. Sci. 2013, 435, 218-225. [CrossRef]

42. Ugarte, P.; Duran, P.; Lasobras, J.; Soler, J.; Menendez, M.; Herguido, J. Dry reforming of biogas in fluidized bed; process intensification. Int. J. Hydrog. Energy 2017, 42, 13589-13597. [CrossRef]

43. Kumar, S.; Kumar, B.; Kumar, S.; Jilani, S. Comparative modeling study of catalytic membrane reactor configurations for syngas production by $\mathrm{CO}_{2}$ reforming of methane. J. $\mathrm{CO}_{2}$ Util. 2017, 20, 336-346. [CrossRef]

44. Leimert, J.M.; Karl, J.; Dillig, M. Dry reforming of methane using a nickel membrane reactor. Processes 2017, 5, 82. [CrossRef]

45. Ben-Mansour, R.; Abuelyamen, A.; Habib, M.A. CFD modeling of hydrogen separation through Pd-based membrane. Int. J. Hydrog. Energy 2020, 45, 23006-23019. [CrossRef]

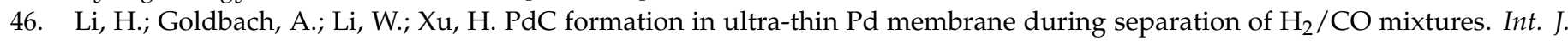
Hydrog. Energy 2016, 41, 10193-10201. [CrossRef]

47. Nishimura, A.; Ohata, S.; Okukura, K.; Hu, E. The Impact of Operating Conditions on the Performance of a CH4 Dry Reforming Membrane Reactor for H2 Production. J. Energy Power Technol. 2020, 2, 1-19. [CrossRef]

48. Zhang, J.; Wang, H.; Dalai, A.K. Kinetic studies of carbon dioxide reforming of methane over Ni-Co/Al-Mg-O bimetallic catalyst. Ind. Eng. Chem. Res. 2009, 48, 677-684. [CrossRef]

49. Avetisov, A.K.; Rostrup-Nielsen, J.R.; Kuchaev, V.L.; Hansen, J.H.B.; Zyskin, A.G.; Shapatina, E.N. Steady-state kinetics and mechanism of methane reforming with steam and carbon dioxide over Ni catalyst. J. Mol. Catal. A Chem. 2010, 315, 155-162. [CrossRef]

50. Richardson, J.T.; Paripatyadar, S.A. Carbon dioxide reforming of methane with supported rhodium. Appl. Catal. 1990, 61, 293-309. [CrossRef]

51. Quiroga, M.M.B.; Luna, A.E.C. Kinetic analysis of rate data for dry reforming of methane. Ind. Eng. Chem. Res. 2007, 46, 5265-5270. [CrossRef]

52. Benguerba, Y.; Virginie, M.; Dumas, C.; Ernst, B. Computational fluid dynamics study of the dry reforming of methane over $\mathrm{Ni} / \mathrm{Al}_{2} \mathrm{O}_{3}$ catalyst in membrane reactor. Coke deposition. Kinet. Catal. 2017, 58, 328-338. [CrossRef]

53. Tsuneki, T.; Shirasaki, Y.; Yasuda, I. Hydrogen permeability of palladium-copper alloy membranes. J. Jpn. Inst. Met. 2006, 70, 658-661. [CrossRef]

54. Fan, M.S.; Abdullah, A.Z.; Bhatia, S. Utilization of greenhouse gases through dry reforming: Screening of nickel-based bimetallic catalysts and kinetic studies. ChemSusChem 2011, 4, 1643-1653. [CrossRef]

55. Jang, W.J.; Shim, J.O.; Kim, H.M.; Yoo, S.Y.; Roh, H.S. A review on dry reforming of methane in aspect of catalytic properties. Catal. Today 2019, 324, 15-26. [CrossRef] 
56. Lee, B.; Lim, H. Parametric studies for $\mathrm{CO}_{2}$ reforming of methane in a membrane reactor as a new $\mathrm{CO}_{2}$ utilization process. Korean J. Chem. Eng. 2017, 34, 199-205. [CrossRef]

57. Neni, A.; Benguerba, Y.; Balsamo, M.; Erto, A.; Ernst, B.; Benachour, D. Numerical study of sorption-enhanced methane steam reforming over $\mathrm{Ni} / \mathrm{Al}_{2} \mathrm{O}_{3}$ catalyst in a fixed-bed reactor. Int. J. Heat Mass Transf. 2021, 165, 120635. [CrossRef]

58. Chen, K.; Zhao, Y.; Zhang, W.; Feng, D.; Sun, S. The intrinsic kinetics of methane steam reforming over a nickel-based catalyst in a micro fluidized bed reaction system. Int. J. Hydrog. Energy 2020, 45, 1615-1628. [CrossRef]

59. Marcoberardino, G.D.; Foresti, S.; Binotti, M.; Manzolini, G. Potentiality of a biogas membrane reformer for decentrailized hydrogen production. Chem. Eng. Process. Process Intensif. 2018, 129, 131-141. [CrossRef] 